\title{
Clinical significance of human papillomavirus infection of the uterine cervix in the development of cervical intraepithelial neoplasia
}

\author{
D CHEETHAM,* J SMITH,† C WILSON,† P E MUNDAY* $¥$ AND \\ D V COLEMANT \\ From the Departments of *Venereology, and + Pathology, St Mary's Hospital Medical School, London \\ and $¥ S T D$ Research Group, MRC Clinical Research Centre, Harrow, Middlesex
}

SUMMARY A group of 25 controls and 30 women with lesions of the cervix associated with papillomavirus were studied prospectively by colposcopy and cytology for up to two years to investigate the relation between human papillomavirus (HPV) infection of the cervix and resolution or progression of cervical intraepithelial neoplasia (CIN). We found that the viral changes were transient and that active infection, as judged by repeated colposcopic and cytological examination, resolved in $83 \%$ of the patients. Resolution or persistence of the viral infection did not appear to affect the development of the CIN lesion. The proportion of CIN lesions that resolved and persisted were the same for the study group and the controls. Possible reactivation of latent papillomavirus was noted in three control group patients. Our findings indicate that changes in the cervix associated with papillomavirus should not influence the clinical management or follow up of patients with CIN.

\section{Introduction}

A strong association between human papillomavirus (HPV) infection of the cervix and cervical cancer is widely accepted. Cellular changes associated with papillomavirus, ${ }^{12}$ papillomavirus particles, ${ }^{3}{ }^{4}$ and structural antigens specific to papillomavirus ${ }^{4-7}$ have been found in dysplastic cervical epithelium; and HPV gene sequences have been seen in tissue samples from intraepithelial and invasive squamous carcinomas of the cervix. ${ }^{8-11}$ Although the clinical significance of these findings is not yet known, the regular presence of HPV deoxyribonucleic acid (DNA) in premalignant and malignant lesions of the cervix has led to the suggestion that papillomaviruses may have a role in the development of cervical neoplasia and possibly in the induction of the malignant process. ${ }^{12}{ }^{13}$ Because HPV may affect cervical carcinogenesis, colposcopists and pathologists now usually report the presence of wart virus changes whenever these are seen in cervical

Address for reprints: Dr D V Coleman, Reader in Cytopathology, Department of Pathology, St Mary's Hospital Medical School, London W2 1PG

Accepted for publication 9 November 1983 epithelium. These reports pose a special problem for the clinician, who must evaluate the relevance of the finding for the patient and decide the appropriate treatment. Little is known about the behaviour of lesions of the cervix associated with papillomavirus or their clinical significance, and there is no consensus on how patients with them should be managed. Firm guidelines on patient management cannot be drawn up until more data on the natural history of these lesions have been obtained.

To determine the natural history of wart virus infection of the cervix and to investigate its clinical relevance for the patient with respect to her risk of developing invasive cervical cancer, we carried out a prospective study of women with lesions of the cervix associated with papillomavirus. Our aim was to investigate the relation between the wart virus status of the cervix and resolution or progression of the cervical intraepithelial neoplasia (CIN). For this purpose, a group of women with CIN 1 or 2 and papillomavirus associated lesions was kept under colposcopic and cytological observation for up to two years without surgical or other intervention. At the end of this time the pathological changes in the cervices of this group of women were compared with those of two control groups that had been monitored over a similar period of time. 


\section{Patients and methods}

Approval for this study was obtained from the ethics committee of St Mary's Hospital. The study group and the controls were drawn from 200 women attending the Praed Street Clinic since May 1981 who, on routine examination, were found to have an abnormal cervical smear or genital warts. At the first visit the patient was interviewed and examined by colposcopy. We observed the appearance of the cervical epithelium before and after the application of acetic acid, and noted changes suggestive of wart virus infection. The criteria for the colposcopic and cytological diagnosis of this infection have been well described. ${ }^{1214}$ is We made a colposcopic diagnosis of wart virus infection when an area of the cervix was roughened or papilliferous. A cervical smear was taken, stained by the Papanicolaou method, and examined in the light microscope for evidence of malignancy. A cytological diagnosis of wart virus infection was recorded when koilocytes or balloon cells, ${ }^{1}{ }^{2}$ which are characteristic of this infection, were seen in the smear. We sought cytological evidence of specific infection with Trichomonas vaginalis, Candida albicans, and herpes simplex virus. Specimens taken from the cervix and the urethra were examined for evidence of infection with various organisms including Neisseria gonorrhoeae, Candida albicans, herpes simplex virus, cytomegalovirus, and Chlamydia trachomatis.

The colposcopic, cytological, and microbiological investigations were repeated at intervals of three months.

\section{Results}

FINDINGS ON ADMISSION TO THE STUDY Fifty five women attended at regular intervals of three months for nine months or more, and form the basis of this report. They were divided into three groups according to the clinical, colposcopic, and cytological findings on admission to the study: Group 1 (study group) (30 women with changes suggestive of wart virus infection of the cervix and mild or moderate dyskaryosis of the squamous cells in the Papanicolaou smear consistent with CIN 1 or 2); Group II (CIN controls) (13 women with changes consistent with CIN 1 or 2, but no evidence of cervical wart virus infection), Group III (healthy controls) (12 women with healthy cervices.) Table I shows the mean age, social class, racial origin, number of sexual partners, mean age at first intercourse, and length of time studied of each group. There were no appreciable differences between the three groups.
TABLE I Demographic details of 55 women studied for at least nine months

\begin{tabular}{|c|c|c|c|}
\hline & $\begin{array}{l}\text { Group I } \\
\text { (WVI and } \\
C I N 1 / 2) \\
(n=30)\end{array}$ & $\begin{array}{l}\text { Group II } \\
\text { (Only } \\
C I N \text { 1/2) } \\
(n=13)\end{array}$ & $\begin{array}{l}\text { Group III } \\
\text { (Healthy } \\
\text { controls) } \\
(n=12)\end{array}$ \\
\hline $\begin{array}{l}\text { Mean age (years) } \\
\text { Age range (years) } \\
\text { Racial group }\end{array}$ & $\begin{array}{l}24 \\
16-35\end{array}$ & $\begin{array}{l}30 \\
20-40\end{array}$ & $\begin{array}{l}26 \\
19-40\end{array}$ \\
\hline $\begin{array}{l}\text { Kacral group } \\
\text { White }\end{array}$ & & 8 \\
\hline West Indian & 3 & 1 & 2 \\
\hline Asian & 0 & i & 2 \\
\hline Social class I & 3 & 0 & 0 \\
\hline II & 7 & 5 & 4 \\
\hline III & 17 & 4 & 7 \\
\hline IV & $\mathbf{0}$ & 1 & 0 \\
\hline other & 5 & 3 & 1 \\
\hline \multicolumn{4}{|l|}{ Mean age at first } \\
\hline intercourse (years) & 17 & $18 \cdot 6$ & 18 \\
\hline Mean no of sexual partners* & 9 & 13 & 16 \\
\hline Mean time studied (months) & 13 & 12 & 14 \\
\hline Range of time studied (months) & $9-24$ & $10-20$ & $10-21$ \\
\hline
\end{tabular}

WVI = wart virus infection; $\mathbf{C I N}=$ cervical intraepithelial neoplasia *Excluding five prostitutes (three in group I, one each in groups II and III).

\section{CHANGES DURING THE STUDY}

Table II shows the changes seen on cytological examination of the three groups of women during the study. The CIN lesions resolved in $12(40 \%)$ of the 30 patients in Group I but persisted in the remaining 18. After the second or third visit wart virus infected cells disappeared from the smears from $25(83 \%)$ of the 30 patients in this group including all 12 whose CIN lesions had resolved. The CIN lesions resolved in five $(38.5 \%)$ of the 13 women in Group II and persisted in the remaining eight women during the period of observation. Koilocytes appeared in later smears from three of the eight women whose CIN lesions persisted. None of these three women had a history of genital warts or had had a sexual partner with genital warts and it is possible that the appearance of the koilocytes in the smear reflected reactivation of latent infection. Two of the patients in Group III developed a mild dyskaryosis during the course of the study.

TABLE II Changes seen on cytological examination of 55 women during the study (percentages of numbers in groups in parentheses)

\begin{tabular}{|c|c|c|c|}
\hline & $\begin{array}{l}\text { Group I } \\
\text { (WVI and } \\
C I N 1 / 2) \\
(n=30)\end{array}$ & $\begin{array}{l}\text { Group II } \\
\text { (Only } \\
C I N 1 / 2) \\
(n=13)\end{array}$ & $\begin{array}{l}\text { Group III } \\
\text { (Healthy } \\
\text { controls) } \\
(n=12)\end{array}$ \\
\hline $\begin{array}{l}\text { CIN lesion resolved } \\
\text { CIN lesion persisted } \\
\text { WVI persisted } \\
\text { CIN developed }\end{array}$ & $\begin{array}{l}12(40) \\
18(60) \\
5(17) \\
\text { not relevant }\end{array}$ & $\begin{array}{l}5(38 \cdot 5) \\
8(61 \cdot 5) \\
3(23) \\
\text { not relevant }\end{array}$ & $\begin{array}{l}\text { not relevant } \\
\text { not relevant } \\
\text { not relevant } \\
2(16 \cdot 7)\end{array}$ \\
\hline
\end{tabular}

WVI = wart virus infection; $\mathrm{CIN}=$ cervical intraepithelial neoplasia . 
HISTORY OF GENITAL WARTS AND PRESENCE OF OTHER GENITAL INFECTIONS

Table III shows that $17(31 \%)$ of the 55 women in the study had a history of genital warts. Only six (11\%) reported the presence of genital warts in their consorts. Chlamydia trachomatis was the organism most commonly isolated from the cervix, and was recovered from $12(22 \%)$ of the women on at least one occasion and from six on more than one occasion. Cytomegalovirus was isolated from two patients, one of whom was also infected with chlamydiae. Trichomonas vaginalis and Candida albicans were found only in cervical smears from patients in the study group. Neither herpes atypia nor herpes simplex virus was isolated from any of the patients in this study.

TABLE III History of and exposure to genital warts and presence of other genital infections

\begin{tabular}{llll}
\hline & $\begin{array}{l}\text { Group I } \\
(W V I \text { and } \\
\text { CIN I/2) } \\
(n=30)\end{array}$ & $\begin{array}{l}\text { Group II }(\text { II } \\
\text { CIN }(n=13)\end{array}$ & $\begin{array}{l}\text { Group III } \\
(\text { Healthy } \\
\text { controls) } \\
(n=12)\end{array}$ \\
\hline $\begin{array}{l}\text { History of } \\
\text { genital warts }\end{array}$ & 10 & 3 & 4 \\
$\begin{array}{l}\text { History of common } \\
\text { skin warts }\end{array}$ & 12 & 7 & 4 \\
$\begin{array}{c}\text { Exposure to genital } \\
\text { warts in partner }\end{array}$ & 3 & 1 & 2 \\
$\begin{array}{l}\text { Chlamydia trachomatis } \\
\text { isolated from cervix }\end{array}$ & 7 & 1 & 4 \\
$\begin{array}{c}\text { Cytomegalovirus } \\
\text { isolated from cervix }\end{array}$ & 1 & 1 & 0 \\
$\begin{array}{c}\text { Candida albicans } \\
\text { isolated from cervix }\end{array}$ & 2 & 0 & 0 \\
$\begin{array}{c}\text { Trichomonas vaginalis } \\
\text { isolated from cervix }\end{array}$ & 2 & 0 & 0 \\
\hline WVI = wart virus infection; CIN $=$ cervical intraepithelial neoplasia.
\end{tabular}

\section{Discussion}

After the start of this study Kauffman and other leading American gynaecologists and pathologists voiced their concern about the lack of knowledge regarding the significance of a clinical diagnosis of HPV infection of the cervix. ${ }^{16}$ They called for caution in the clinical management of patients with such diagnoses until more is known of the natural history of cervical wart virus infection. ${ }^{16}$ This study provides some of the information Kauffman and his colleagues have called for.

Our results showed that the presence of wart virus infections in the cervical epithelium did not affect the percentage of cases $(40 \%$ of women with evidence of wart virus infection and $38.5 \%$ of women without such changes) in which CIN lesions resolved. We have also shown that such wart virus changes may be transient, as they are at other sites, and that they develop or resolve independently of the CIN lesions. Although virus infected cells disappeared from the smears from $25(83 \%)$ of the 30 study group patients, the CIN lesions persisted in $13(52 \%)$.

We considered the role of other socioeconomic, sex related, and infective factors in this study, and showed that there was no appreciable difference between the study group and controls in respect of these variables. Chlamydia trachomatis and cytomegalovirus were isolated most frequently, and herpex simplex infection was not found.

The study group was composed of women who had morphological evidence of wart virus infection of the cervical epithelium, as judged by repeated colposcopy and cytological examination. We know that not all cases of HPV infection are detected by these techniques, and have shown that papillomaviruses may be present in the cervix in the absence of cytopathic changes in the epithelium. Papillomavirus antigen has been shown in a small percentage of normal cervical biopsy specimens and in $14 \%$ of CIN lesions which do not show wart virus associated changes. ${ }^{17}$ Walker observed a correlation between the colposcopic and histological findings in only $83 \%$ of cases of wart virus infection. ${ }^{15}$ Thus a number of women among the controls may also have been harbouring the virus in the cervical epithelium. The development of wart virus changes in three women with CIN in control group II suggests that this was the case. Nevertheless, within the limitations of this approach, which is widely used in routine clinical practice, we conclude that active infection of the cervix with papillomaviruses should in no way influence the clinical management of patients with CIN. We therefore endorse the suggestion of Kauffman et al that women with colposcopic and cytological evidence of changes associated with papillomavirus should receive the same clinical and colposcopic evaluation and follow up that is usually given to women with conventional forms of CIN.

We stress the preliminary nature of this report, which draws on data from 55 women who are part of a much larger prospective study. As the study proceeds, we expect to be able to obtain more accurate data with respect to the prevalence of HPV in the cervix by developing an objective DNA hybridisation technique to detect infection in cervical smears. Recent research has shown that there are at least three types of HPV in the female genital tract-HPV 6, 11, and $16 .^{8-11}$ HPV 6 and 11 are most frequently found in anogenital warts. In contrast, HPV 16 is prevalent in cancerous epithelium, which suggests its possible involvement in the malignant process. By studying the prevalence of these viruses in cervical smears and correlating the virus type in each case with the outcome of cervical pathology, we 
may identify the HPV types associated with progression or resolution of CIN and thereby establish risk factors for invasive cancer. The study group also provides scope for investigating sexual transmission of infection, immunological control of wart virus infection, and methods of treatment, and we plan further research into these aspects of infection.

This study was supported by a grant from the Cancer Research Campaign to St Mary's Hospital Medical School (Exp Path IV). We thank the department of virology at St Mary's Hospital and the division of communicable diseases, Clinical Research Centre, Harrow for their help with the microbiological studies. We also thank Dr J R W Harris, Director of the Praed Street Clinic, for his support, and Ms Anne Morse, chief MLSO in cytology, and Miss Annette Steele, Medical Student at St Mary's Hospital, for their help.

\section{References}

1. Meisels A, Fortin R. Condylomatous lesions of the cervix and vagina. I Cytologic patterns. Acta Cytol 1976; 20:505-9.

2. Meisels A, Fortin R, Roy M. Condylomatous lesions of the cervix II Cytologic, colposcopic and histopathologic study. Acta Cytol 1977;21:379-90.

3. Hills E, Laverty CR. Electron microscopic detection of papilloma virus particles in selected koilocytotic cells in a routing cervical smear. Acta Cytol 1979; 23:53-6.

4. Ferenczy A, Braun L, Shah KV. Human papillomavirus (HPV) in condylomatous lesions of the cervix. A comparative ultrastructural and immunohistochemical study. Am J Surg Pathol 1981;5:661-70.

5. Kurman RJ, Shah KH, Lancaster WD, Jenson AB. Immunoperoxidase localisation of papillomavirus antigens in cervical dysplasia and vulvar condylomas. Am J Obstet Gynecol 1981;40:931-5.
6. Walker PG, Singer A, Dyson JL, Shah KV, To A, Coleman D. The prevalence of human papillomavirus antigen in patients with cervical intraepithelial neoplasia. $B r J$ Cancer 1983; 48:99-101.

7. Kurman RJ, Sanz LE, Jenson AB, Perry S, Lancaster WD. Papillomavirus infection of the uterine cervix. I Correlation of histology with specific structural antigens and DNA Sequences. International Journal of Gynaecological Pathology 1982;1:17-28.

8. McCance DJ, Walker PG, Dyson JL, Coleman DV, Singer A. Presence of human papillomavirus DNA in cervical intraepithelial neoplasia (CIN). Br Med J 1983;287:784-8.

9. Gissmann L, Devilliers E, Zur Hausen H. Analysis of human genital warts (condylomata accuminata) and other genital tumours for human papillomavirus type 6 DNA. Int $J$ Cancer 1982;29: 143-6.

10. Gissmann L, Wolnik, Ikenberg H, Koldovsky U, Schnurch HG, Zur Hausen A. Human papillomavirus type 6 \& 11 DNA sequences in genital and laryngeal papillomas and some cervical cancers. Proc Natl Acad Sci USA 1983;80:560-3.

11. Durst MI, Gissmann L, Ikenberg $H$, Zur Hausen $H$. A papillomavirus DNA from a cervical carcinoma and its prevalence in cancer biopsy samples from different geographic regions. Proc Natl Acad Sci USA 1983;80:3812-5.

12. Reid R, Stanhope CR, Herschman BR, Booth E, Phibbs GD, Smith JP. Genital warts and cervical cancer. I Evidence for an association between subclinical papillomavirus infection and cervical malignancy. Cancer 1982; 50:377-87.

13. Zur Hausen $\mathbf{H}$. Human genital cancer: synergism between two virus infections or syngerism between a virus infection and initiating events. Lancet, 1983 ; ii, 1370-2.

14. Kirkup W, Evans AS, Brough AK, Davis JA, O'Loughlin T, Wilkinson G, Monaghan JM. Cervical intra-epithelial neoplasia and 'warty' atypia: a study of colposcopic, histological and eytological characteristics. $\mathrm{Br} J$ Obster Gynaecol 1982; 89:571-7.

15. Walker PB, Singer A, Dyson JL, Shah KV, Wilters $S$ Coleman DV. Colposcopy in the diagnosis of papillomavirus infections of the uterine cervix. Br J Obstet Gynaecol 1983; 90: $1082-6$.

16. Kauffman R, Koss LG, Kurman RJ, et al. Statement of caution in the interpretation of papillomavirus-associated lesions of the epithelium of the uterine cervix. Acta Cytol 1983;27: $107-8$.

17. Walker $M$, Pomfret C, Valkova B, Anderson MC Cheetham D, Coleman DV. Prevalence of papillomavirus specific antigen in normal cervical epithelium (in press). 